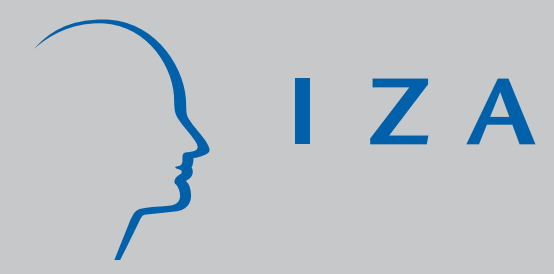

IZA DP No. 2301

The Earnings of American J ewish Men: Human Capital, Denomination and Religiosity

Barry R. Chiswick Jidong Huang

September 2006 


\title{
The Earnings of American Jewish Men: Human Capital, Denomination and Religiosity
}

\author{
Barry R. Chiswick \\ University of Illinois at Chicago \\ and IZA Bonn \\ Jidong Huang \\ University of Illinois at Chicago
}

\section{Discussion Paper No. 2301 September 2006}

\author{
IZA \\ P.O. Box 7240 \\ 53072 Bonn \\ Germany \\ Phone: +49-228-3894-0 \\ Fax: +49-228-3894-180 \\ Email: iza@iza.org
}

Any opinions expressed here are those of the author(s) and not those of the institute. Research disseminated by IZA may include views on policy, but the institute itself takes no institutional policy positions.

The Institute for the Study of Labor (IZA) in Bonn is a local and virtual international research center and a place of communication between science, politics and business. IZA is an independent nonprofit company supported by Deutsche Post World Net. The center is associated with the University of Bonn and offers a stimulating research environment through its research networks, research support, and visitors and doctoral programs. IZA engages in (i) original and internationally competitive research in all fields of labor economics, (ii) development of policy concepts, and (iii) dissemination of research results and concepts to the interested public.

IZA Discussion Papers often represent preliminary work and are circulated to encourage discussion. Citation of such a paper should account for its provisional character. A revised version may be available directly from the author. 
IZA Discussion Paper No. 2301

September 2006

\section{ABSTRACT \\ The Earnings of American Jewish Men: Human Capital, Denomination and Religiosity*}

This paper analyzes the determinants of the earnings of American Jewish men using the 2000/01 National Jewish Population Survey. Non-response to the question on earnings is analyzed. Earnings are related to conventional human capital variables, as well as Jewishspecific variables. Except for the size of place and region variables, the standard human capital variables have similar effects for Jews and the general population. Jewish day schooling as a youth enhances earnings. Earnings vary by denomination, with Conservative Jews earning the most. The effect on earnings of religiosity (measured by synagogue attendance) is not monotonic. Earnings are highest for those who attend only once a week.

JEL Classification: J310, J150, Z120, C810

Keywords: earnings, Jews, religion, denomination

Corresponding author:

Barry R. Chiswick

Department of Economics (M/C 144)

University of Illinois at Chicago

601 South Morgan Street

Chicago, IL 60607-7121

USA

E-mail: brchis@uic.edu

\footnotetext{
* We appreciate the comments on an earlier draft from Paul Burnstein, Carmel U. Chiswick, Danny Cohen-Zada, Roberta Farber, Allan Glicksman, Robert Goldfarb, Allan Kensky, Evelyn Lehrer, Uzi Rebhun, and William Sander.
} 


\section{“The Earnings of American Jewish Men: Human Capital, Denomination and Religiosity”}

Revised August 2006

\section{INTRODUCTION}

Research has shown that there is substantial variation by race, ethnicity and religion in the educational attainment and earnings of adult men and women in the United States. American Jews, for example, have been shown to have a higher educational level, higher occupational status and higher earnings than other whites, both overall and when education and other variables are held constant. ${ }^{1,2}$

The U.S. Census of Population has never explicitly included a question on religion. ${ }^{3}$ Since Jews are currently only about 2 percent of the population of the United States, the sample sizes for Jews in privately collected surveys are relatively small. As a result, studies that have identified Jews have tended to use indirect Jewish identifiers or,

\footnotetext{
${ }^{1}$ For recent research regarding Jewish men and women, see, for example, B. Chiswick (1993, 1999, 2006), Burstein (2005), Lehrer (2006a, 2006b) and Lieberson and Waters (1988), and the references therein.

${ }^{2}$ The comparison with other whites is appropriate. Of the male Jewish respondents in the 2000/01 National Jewish Population Survey (NJPS), 97 percent report their race as white. This is consistent with the racial distribution of Jews in the General Social Survey, 96 percent white non-Hispanic, 1 percent Hispanic, 2 percent Black and 1 percent Asian (Smith, 2005, p. 287).

${ }^{3}$ The Census Office conducted a special survey of about 10,000 American Jewish families in 1890, and asked occupation but not earnings. In March 1957, the Current Population Survey (conducted by the Census Bureau for the Bureau of Labor Statistics) for the first and last time included a question on religion, in addition to the standard questions on employment, earnings and occupation. Microdata files do not exist for either sample. See Billings (1980), B. Chiswick (2001) and the U.S. Bureau of the Census (1958, no date). Since 1970, the dicennial census has included a question on ancestry, but when the responses are coded, the coding system masks any response that might reveal the person's religion.
} 
if there is a direct Jewish identifier, to be of relatively modest size. Data on Jews are also available from surveys conducted by local Jewish communities and from the 1970, 1990 and 2000/01 National Jewish Population Surveys. With the exception of the 2000/01 NJPS, these Jewish surveys generally do not ask about individual earnings. Yet, even with these data limitations, when roughly comparable results emerge from a variety of independent data sets one has considerable confidence in the robustness of the findings of higher levels of schooling and earnings among American Jews.

The data sets that revealed the higher levels of schooling and earnings of American Jews have generally had too few observations on Jews to perform statistically meaningful analyses for Jews using multivariate techniques. Pooling the data from different surveys is not practical because these surveys used somewhat different methodologies and questions for identifying Jews and for other variables. Moreover, some matters of interest that relate specifically to Jews cannot be addressed because relevant questions are not included. For example, does Jewish denomination matter for the earnings of Jews, and does this depend on whether it is childhood or current denomination?

Fortunately, the National Jewish Population Survey 2000/01 (NJPS 2000/01) asked earnings and other relevant questions for a sufficiently large sample of adult Jewish men to conduct a statistical analysis of their earnings. These data are analyzed here to provide the first systematic analysis of the determinants of earnings of adult (age 25 to 64) American Jewish men. The analysis is limited to male respondents because of the additional complexity of incorporating labor supply into the analysis of earnings for women and the limited data on labor supply in the NJPS. 


\section{NATIONAL JEWISH POPULATION SURVEY}

The National Jewish Population Survey (NJPS) 2000/01 employed a two step survey procedure. A set of screener questions was administered by telephone to a large stratified random sample of the U.S. population, selected by random digit dialing, to identify households that included at least one person who is currently Jewish or is of Jewish ancestry or origin, broadly defined. ${ }^{4}$ Using these data, a stratified random sample of about 4,500 households was selected that had been identified in the screener survey as including at least one Jewish person. One randomly selected adult in the household was designated the respondent, without regard for that person's current religion or Jewish origin or ancestry. That respondent was interviewed by telephone about himself or herself, and about other household members.

The questionnaire inquired about the respondent's current demographic and labor market characteristics, and about the respondent's religion, parent's religion, religious practices, Jewish education, and involvement in Jewish-related activities while the respondent was being raised and currently. Many of the same questions, but not all, were asked about other household members, including the respondent's spouse, if any.

\footnotetext{
${ }^{4}$ For descriptions of and access to the NJPS data (as of August 29, 2006), see: NJPS Description at http://www.ujc.org/content_display.html?ArticleID=10451

NJPS Methodological Appendix at http://www.ujc.org/content_display.html?ArticleID=83786
}

NJPS Methodology Series Index at http://www.ujc.org/content_display.html?ArticleID=84100

The NJPS 2000/01 data are available from the North American Jewish Data Bank at http://www.jewishdatabank.org/ 
The NJPS 2000/01 serves as the basis for this study's analysis of the earnings of adult male American Jewish respondents. The previous NJPS surveys (1990 and 1970) and most communal Jewish surveys cannot be used for this purpose because they do not ask the earnings of individuals, although they may ask about household income. Note that the NJPS 2000/01 was a stratified random sample with an oversampling of denser Jewish communities. Thus respondent weights are applied in the analysis conducted here. Because earnings and other labor market information was inadvertently not asked of the spouses of the respondents in some of the "replicates" the sample size for spouses is substantially reduced.

While it would be desirable for comparative purposes to have a sufficiently large random sample of non-Jews in the NJPS, this is not the case. The non-Jewish respondents are in households with at least one Jewish person. They do not constitute a random sample of non-Jews.

\section{STATISTICAL METHODOLOGY}

The analysis of earnings among adult Jewish men is conducted in a two-stage procedure. Among the adult male respondents, age 25 to 64 years, who worked and had an occupation in the year prior to the survey, about one-third refused to respond to the question on their earnings. Thus, the analysis of the data on earnings might be subject to sample selectivity bias. That is, the individuals who reported their earnings may not be a random sample of the Jewish survey respondents.

Thus, the first stage in the study of earnings is the analysis of the determinants of who responded to the earnings question. For this stage a dichotomous variable is created which equals one if the respondent answered the question on earnings and equals zero if 
the respondent did not answer the question. This analysis is first performed using Ordinary Least Squares (OLS) analysis and then, because of the dichotomous dependent variable, performed using Logit analysis. The results are shown to be independent of the statistical methodology.

In the second stage, earnings are analyzed for those who reported their earnings. Using the "human capital earnings function", a standard technique for analyzing earnings, the natural logarithm of annual earnings as reported in the NJPS 2000/01 is regressed on a set of explanatory variables, including years of schooling, years of labor market experience, marital status, region in the U.S., nativity, denomination when raised, current denomination, and whether the respondent converted to Judaism, among other variables. Data on the type and extent of Jewish education are also analyzed. The analysis of earnings is performed in two ways, using Ordinary Least Squares and using the Heckman selectivity correction technique to adjust for sample selection bias due to the non-reporting of earnings.

\section{STATISTICAL ANALYSIS}

Appendix Table A lists the dependent and explanatory variables used in this analysis, defines these variables, and indicates the relevant questions from the NJPS 2000/01. Appendix Table B lists the variables, the sample size, and descriptive statistics (mean, standard deviation, and minimum and maximum values).

The American Jewish men have a high level of schooling, a mean of 15.7 years, and are older, 44 years, than the general population of adult white men in the United 
States. ${ }^{5}$ Nearly two thirds are currently married (62 percent), nearly all (90 percent) live in metropolitan areas, and less than a quarter (23 percent) live in the 17 Southern states and the District of Columbia. About 15 percent were foreign born, with one-third of these from the Former Soviet Union and nearly one-third from other Developed Countries (primarily Europe). By occupation, over half (54 percent) are in professional and managerial jobs, with 21 percent in sales and clerical jobs, and 10 percent in blue collar work, with another 15 percent in other occupations or have occupation missing. ${ }^{6}$ The self-employed, who can be in any occupation, comprise 15 percent of the men in the sample.

Table 1 is an analysis (using OLS in columns 1 and 2 and Logit analysis in column 3) of the determinants of who reported earnings among adult male respondents who worked in the year prior to the NJPS survey. The dependent variable is coded as 1 if the respondent answered the earnings question. The explanatory power of the equation is very low, only 6 percent. Very few variables are statistically significant. Responding to the earnings question is unrelated to educational attainment, nativity, the density of the Jewish population in the state (the concentration ratio in column 2), and whether the respondent lives in a metropolitan area. The propensity to respond is greater among those in sales and clerical occupations than among those in other jobs. Responding

\footnotetext{
${ }^{5}$ Those identified as non-Jews in the NJPS constituted less than one percent of the sample of adult male respondents in the NJPS. They are not representative of the non-Jewish population of the U.S.

${ }^{6}$ For an analysis of the occupational distribution and self-employment of American Jewish men in the 1990 and 2000/01 NJPS in comparison to non-Jewish white men in the U.S. Census, see B. Chiswick (2006).
} 
decreases with age, and is greater for those who are separated compared to those currently married (the benchmark). It is less common among Jews in the South.

The equations in Tables 2 and 3, columns (1) to (3), parallel equations computed for adult men in the general U.S. labor market. The regression analysis of earnings is reported in Table 2 using Ordinary Least Squares and in Table 3 using the Heckman selectivity technique to correct for sample selection bias, in this case, that the respondent reported earnings. The selection equation is based on Table 1 , column 2 . The statistically significant positive "lambda" term in Table 3 indicates positive selectivity into the category of reporting earnings. That is, for unmeasured reasons, those who report their earnings have higher earnings in the NJPS than those who refuse to do so. By comparing Tables 2 and 3 it is clear that the adjustment for selectivity does not have any substantive effects on the interpretation of the findings for the explanatory variables in the analysis of earnings.

Years of schooling has a highly statistically significant effect on earnings. Earnings increase by about 11 percent for each additional year of schooling in the OLS analysis and by about 10 percent in the selectivity corrected analyses (Tables 2 and 3). Earnings increase at a decreasing marginal rate for each additional year of labor market experience. Although only the squared experience term in Table 2 is statistically significant, the set of experience variables is statistically significant. In this table, earnings increase by about 2 percent per year during the early years in the labor market, and the effect diminishes slightly with a longer experience in the labor market. Men who are currently married earn about 26 percent more than men who never married, other variables being the same, and they earn about 5 percent more than previously married 
(widowed, divorced, separated) men, but this latter difference is not statistically significant. These findings are of the same order of magnitude as the effects on earnings for the general native-born white male population in the 2000 Census (Chiswick and Miller, 2006).

At arrival the foreign born Jewish men earn about 24 percent less than U.S.-born Jewish men, but the gap narrows by about one percentage point per year that the immigrant has lived in the United States (Tables 2 and 3, column 1). This suggests an earnings "catch-up” at about 20 to 25 years of residence among the immigrants. When specific regions of birth are separately identified it appears that only those born in the former Soviet Union have earnings that differ significantly, and substantially, from those of the native born (Tables 2 and 3, columns 2 and 3). Those from the other Developed Countries, Israel and Less Developed Countries had a longer period of residence in the United States and they essentially closed the earnings gap, in contrast to the recently arrived immigrants from the former Soviet Union. ${ }^{7}$

Thus far, the analysis for American Jews has paralleled analyses for adult men in general in the U.S. labor market. The results for schooling, labor market experience, marital status and nativity are quite similar to the results for the general labor market. It should be noted, however, that while in the general labor market the earnings of white men are lower in the South and higher in metropolitan areas, there is no effect of region among Jews. This implies that compared to non-Jews living in the same areas, Jewish

${ }^{7}$ For an analysis of the earnings of Soviet Jewish immigrants compared to other immigrants and the native born in the United States using census data, see Chiswick and Wenz (2006). 
men earn relatively more in the South and in non-metropolitan areas. That is, Jewish men appear to earn more in areas where there are relatively fewer Jews. ${ }^{8}$

The last three columns in Tables 2 and 3 add variables that are unique to the NJPS - the denomination in which the respondent was raised and the current denomination. ${ }^{9}$ The detailed list of denominations identified in the NJPS was collapsed into six categories (see Appendix Table A). The Conservative Jews serve as the benchmark. When the analysis is performed using denomination raised, Conservative Jews have the highest earnings, but their earnings do not differ significantly from those who say they were raised Orthodox or Reform. Those who report that they were raised “just Jewish”,

\footnotetext{
${ }^{8}$ This is consistent with Jews requiring a wage premium to live and work in areas where there is a smaller or non-existent Jewish community. This may be due to the higher cost of Jewish-specific ethnic goods, defined broadly, in such areas. For a further development of this approach, see Chiswick and Miller (2005).

${ }^{9}$ Contemporary American Judaism is a decentralized congregation-based religion with three major synagogue movements, Reform, Conservative and Orthodox. These movements are confederations of synagogues which are managed by their congregants, rather than by central authorities. Each of these movements has evolved its practices over the past century and individuals are free to join any synagogue that they wish. Reform Judaism, originally the product of mid- $19^{\text {th }}$ century German Jewish immigrants, relaxed many of the "traditional" laws and customs to "Americanize" Judaism. Although many of its "reforms" have been reversed, it is still the least time intensive, imposes the fewest restrictions on the behavior of adherents, and generally requires of its congregants the least Jewish human capital (e.g., knowledge of Hebrew, the laws and customs, and prayers). Conservative Judaism, established in the late- $19^{\text {th }}$ century as a reaction to the Reform movement, sought to "conserve" elements of traditional practice while at the same time adapting to the Americanization of its congregants. Although Orthodox Judaism has its sub-denominations (e.g., Modern Orthodox, Hasidim), it adheres more closely to the "traditional" religious practice of late $19^{\text {th }}$-century Eastern Europe, is more time intensive and for full participation generally requires of its congregants more Jewish human capital than Conservative Judaism. The Orthodox are more likely to live in close communities because of the need to be near synagogues (e.g. riding and handling money is proscribed on the Sabbath and certain major holidays), Jewish schools, and for other ethnic goods (e.g., kosher foods).
} 
secular, or non-Jewish have significantly lower earnings, with the latter two categories having earnings that are lower by about 40 percent compared to Conservative Jews. ${ }^{10}$

Denomination raised can be quite different from current denomination because of movements across these categories (See Appendix Tables C and D). Some become less attached while others become more attached to traditional religious practice. Considering current denomination, only the Orthodox and the secular Jews have earnings that are statistically different from the Conservative Jews, about 30 percent lower earnings for each group. The non-Jews in the sample have much lower earnings, but the difference is at the margin of statistical significance. Converts to Judaism, that is, men born nonJewish but who converted to Judaism, have substantially lower earnings, but as with those currently not Jewish, the small sample size may be responsible for the lack of statistical significance (Tables 2 and 3).

Data are also available in the NJPS 2000/01 on whether the respondent received any Jewish education while in grades 1 to 7 or in grades 8 to 12, and, if so, the type and number of years of this Jewish education. ${ }^{11}$ The "first mentioned" type of Jewish education in each age group is taken to be the predominant one in that age group. ${ }^{12}$ The

\footnotetext{
${ }^{10}$ In a study of Protestants, Lehrer (2006a) finds that those unaffiliated as adults have wages significantly lower than those of mainline Protestants. She also finds (Lehrer 2006b) that young people who grow up with no religious affiliation achieve a lower level of schooling.

${ }^{11}$ The NJPS questionnaire has the breakdown of Jewish education as grades 1 to 7 and 8 to 12 . No finer detail is provided.

${ }^{12}$ Most respondents in the NJPS reported only one type of Jewish education. Of the 3,111 respondents who reported receiving Jewish education in grades 1 to 7, only 358 (11 percent) reported a second type, 57 reported a third type and 6 four types. For grades 8 to 12 , of the 1,591 respondents who received Jewish education, only 75 (5 percent) reported a second type, 10 a third type and 2 a fourth type. Source: National Jewish Population Survey, 2000/01.
} 
responses on type were recoded into three dichotomous variables: Day School (full-time Jewish Day School or Yeshiva, or Israeli Secular/Public Schooling), Other Jewish Education (e.g., part time or one day a week, Bar/Bar Mitzvah lessons, Jewish Studies in public/private school, Jewish home schooling), and None (no Jewish education or only nursery/kindergarten or Jewish summer camp). The type of Jewish schooling received was strongly related to the denomination in which the respondent was raised, with those raised Orthodox receiving the most (particularly Day School), and those raised just Jewish or secular the least. ${ }^{13}$

When the two sets of variables for type of Jewish schooling in grades 1 to 7 and in grades 8 to 12 were entered into the earnings equations (with no Jewish schooling serving as the benchmark), the separate coefficients were not statistically significant, in part due to multicolinearity. When only the grade 8 to 12 Jewish schooling variables were entered, attending a Jewish Day School had a significant positive effect on earnings in the equation where current denomination was held constant. ${ }^{14}$ Other Jewish schooling was

\begin{tabular}{|c|c|c|c|c|}
\hline \multicolumn{2}{|l|}{ Denomination } & \multicolumn{3}{|c|}{ Type of Jewish Schooling (percent) } \\
\hline Raised & Day School & Other & None & Total \\
\hline Orthodox & 46 & 21 & 33 & 100 \\
\hline Conservative & 7 & 40 & 52 & 100 \\
\hline Reform & 0 & 42 & 58 & 100 \\
\hline Just Jewish & 4 & 12 & 83 & 100 \\
\hline Secular & 7 & 5 & 87 & 100 \\
\hline
\end{tabular}

Detail may not add to total due to rounding.

Source: National Jewish Population Survey, 2000/01

${ }^{14}$ Jewish day schools involve a longer school day than do the public schools as students learn both the secular (general) curriculum that they would be exposed to in public schools and the Jewish curriculum, including Hebrew, religious studies, prayers, Jewish 
not significant. Compared to those with no Jewish education, those who reported attending a Jewish Day School for at least some time in grades 8 to 12 had earnings about 30 percent higher than those who had no Jewish education (coefficient $=0.29$, t-ratio=2.2) (Table 4). The "other Jewish education” variable has a very small coefficient and is not statistically significant (coefficient 0.032, t-ratio=0.42) in the equation where current denomination is held constant.

The dichotomous variable for Day School education in grades 8 to 12 can be replaced by a continuous variable for the number of years of this schooling (zero to 5 years). In the current denomination equation its coefficient implies an increase in earnings of 6 percent per year of Jewish Day Schooling (grades 8-12), which is statistically significant at the 10 percent level (coefficient 0.059 , t-ratio 1.74 ). The coefficient of total schooling remains at 11 percent $(t=7.84)$. Thus, controlling for current denomination and other variables, Jewish Day Schooling at the secondary level is associated with higher earnings.

The only dramatic changes in the coefficients of the other explanatory variables when the Jewish education variables (grades 8 to 12) are added to the equation are the increase in the negative effect (and the increase in its statistical significance) on earnings of currently being Orthodox or currently being secular. These coefficients imply that a currently Orthodox Jewish man who attended a Day School (including Yeshiva) in the 8 to 12 grade had earnings 15 percent below that of a currently Conservative Jew who did not attend a Day School, while a currently Orthodox man who did not attend a day school had an even greater earnings disadvantage (coefficient of -0.477). Currently secular

history, etc. In additional to the broader range of studies, the curriculum requires greater discipline and learning to multi-task. 
Jews, who would have been far less likely to have attended a full time Jewish school, have very low earnings (coefficient -0.419) compared to otherwise comparable Conservative Jewish men who also did not attend a day school.

It appears, therefore, that the type of Jewish education received does have an association with earnings in the secular labor market. Receiving part-time Jewish education neither enhances nor detracts from Jewish men's earnings, but attending a Jewish Day School or Yeshiva is associated with substantially greater labor market earnings of about 6 percent per year of this day schooling.

This suggests that full-time Jewish education may enhance earnings because of the complementarity of Jewish focused education and secular studies, perhaps because of the dual curricular program (general and Jewish studies), the longer school day, the emphasis on learning a second language (in this case Hebrew), or learning the analysis of texts (C. Chiswick 2006). Given the limitations of the data, however, it is not possible to control for potentially important determinants of day school education, such as higher innate ability or parental income.

The variables for denomination can be replaced by a measure of religiosity, namely the frequency with which the men attended synagogue services last year. The data on frequency were provided in categories and were recoded as none (did not attend at all), seldom (a few days in the year), monthly (once to three times a month), weekly (once a week), and more than once a week. ${ }^{15}$ Using monthly attendance as the benchmark, there is no effect on earnings of not attending or attending only seldom, earnings are significantly greater among weekly attendees, and earnings are lower

\footnotetext{
${ }^{15}$ Synagogue attendance is greatest for those reporting current denomination as Orthodox and least for those who report they are secular.
} 
(although not always significantly so) among those attending more frequently than weekly. These patterns are largely invariant with respect to whether the Jewish education variables are held constant. ${ }^{16}$

These yearly attendance categories can be transformed into days per year, and entered into the earnings equation in a quadratic manner. The linear term has a positive coefficient and the squared term has a negative sign. ${ }^{17}$ The coefficients imply a "peak" earnings at about 145 days per year, or less than three days per week.

The synagogue attendance data imply that weekly attendees or three day a week attendees have higher earnings than those who attend less often, but that earnings decline with a greater frequency of attendance.

\footnotetext{
${ }^{16}$ Partial effect of frequency of synagogue attendance on earnings (Monthly is benchmark)

None

Seldom

Weekly

More than Weekly

No Control for Jewish Schooing $-0.663$

$(-0.53)$

0.062

$(0.52)$

0.361

(2.02)

$-0.202$

$(-1.02)$

${ }^{17}$ Partial effect of number of days of synagogue attendance last year on earnings:

Days No Control for Jewish Schooling 0.00349

Days Squared

Control for Jewish Schooling

$-0.099$

$(-0.91)$

0.022

$(0.20)$

0.291

(1.64)

$-0.357$

$(-1.98)$

\begin{tabular}{lcc} 
& No Control for Jewish Schooling & Control for Jewish Schooling \\
\cline { 2 - 3 } Days & 0.00349 & 0.00292 \\
& $(1.99)$ & $(1.50)$ \\
Days Squared & -0.000012 & -.000012 \\
& $(-2.19)$ & $(-2.06)$
\end{tabular}
}




\section{Summary and Conclusions}

This paper has been concerned with an analysis of earnings among adult Jewish men as reported in the National Jewish Population Survey, 2000/01.

The analysis of the response to the question on earnings indicates that nonresponse is unrelated to education level. Those in sales and clerical jobs are more likely to report their earnings than the professionals and managers, possibly because they are more likely to be salaried workers and know their earnings with greater certainty. Older workers and those living in the South are less likely to report earnings, and those who are separated from their wives are more likely to respond. Overall, however, there appears to be little systematic pattern in who refused to respond to the question on earnings.

Earnings respond positively to schooling (by about 11 percent per year of schooling), labor market experience, being currently married, being born in the U.S., and, among the foreign born, living in the U.S. a longer period of time. These patterns are quite similar to those found in the general population. Other things the same, only those from the former Soviet Union, the most recent group of Jewish refugees, earn less than Jews born in the U.S. The Soviet Jews have labor market experiences consistent with their being disproportionately recent refugees.

Earnings are associated with denomination. Those raised "just Jewish” or secular have earnings significantly lower than those of Conservative Jews. Those currently Orthodox or secular have earnings lower than currently Conservative Jews. The earnings for other Jews (Reform or “just Jewish”) are lower than those of currently Conservative Jews, other measured variables the same, but the differences are not statistically significant. 
Labor market earnings appears to be associated with Jewish education. In the analysis that includes current denomination, those who attended a full-time Jewish day school (Day School, Yeshiva or Israeli school) at least part of the time in grades 8 to 12 report significantly higher earnings, by about 30 percent. Earnings are increased by about 6 percent per year of Jewish day schooling in grades 8 to 12 . Compared to a currently Conservative Jew who did not attend a Day School, the earnings gap with the currently Orthodox is narrowed if the latter attended, and is widened if he did not. The earnings disadvantage of currently secular Jews is increased if, as is typically the case, they did not attend a Jewish Day School. Part time Jewish education appears to have no effect on earnings in the secular labor market. The Jewish day school effect may be due to its dual curriculum - general studies and Jewish education.

The data on frequency of synagogue attendance suggests a non-monotonic effect on earnings. Other variables the same, earnings are greater for those who attend once a week or a couple of times a week, but are lower for those who attend less frequently or more frequently (nearly daily).

These findings suggest a non-linear effect of religious practice among Jews on their labor market outcomes. Those who are raised without a religious involvement or who as adults are not religiously involved have lower earnings. This suggests that religious involvement as a youth and as an adult is associated with more favorable labor market outcomes. Yet, the less favorable findings for the Orthodox, other variables being the same, and those who attend the synagogue daily, suggests that beyond some point religious practice may have a negative effect on secular labor market earnings. This may arise because, beyond some point, time and effort devoted to religious activities detract 
from the time and/or effort devoted to the labor market. Or, it may be that to maintain an Orthodox life style self-imposed restrictions (on where one lives and works, the days of the week one works, as well as choice of occupation, etc.) limits earnings. Discrimination in the labor market against the Orthodox might also be a factor.

The analysis indicates that in spite of the high rate of refusal to answer the question on earnings, insights can be gained regarding who refused to report their earnings and the determinants of earnings by including a question on individual earnings in communal and national surveys of American Jews, and in comparable surveys for other groups defined by religion or ethnicity. 
Table 1. Determinants of Responding to Earnings Question among Adult Male Respondents Who Worked, NJPS 2000/01

\begin{tabular}{|c|c|c|c|}
\hline & OLS & OLS & Logit (Marginal Effect) \\
\hline \multirow[t]{2}{*}{ Schooling (Years) } & -0.005 & -0.005 & -0.005 \\
\hline & $(0.65)$ & $(0.67)$ & $(0.64)$ \\
\hline \multirow[t]{2}{*}{ Age (Years) } & -0.037 & -0.037 & -0.044 \\
\hline & $(2.63)^{* * *}$ & $(2.66)^{* * *}$ & $(2.64)^{* * *}$ \\
\hline \multirow[t]{2}{*}{ Age Squared } & 0.0003 & 0.0004 & 0.0004 \\
\hline & $(2.20)^{* *}$ & $(2.23)^{* *}$ & $(2.32)^{* *}$ \\
\hline \multirow[t]{2}{*}{ Widowed } & 0.115 & 0.112 & 0.103 \\
\hline & $(0.91)$ & $(0.89)$ & $(0.89)$ \\
\hline \multirow[t]{2}{*}{ Divorced } & 0.064 & 0.063 & 0.061 \\
\hline & $(1.16)$ & (1.13) & $(1.17)$ \\
\hline \multirow[t]{2}{*}{ Separated } & 0.201 & 0.211 & 0.191 \\
\hline & $(2.00)^{* *}$ & $(2.11)^{* *}$ & $(2.26) * *$ \\
\hline \multirow[t]{2}{*}{ Never Married } & 0.034 & 0.036 & 0.039 \\
\hline & $(0.79)$ & $(0.83)$ & $(0.83)$ \\
\hline \multirow[t]{2}{*}{ Self-employed } & -0.036 & -0.035 & -0.035 \\
\hline & $(0.89)$ & $(0.84)$ & $(0.86)$ \\
\hline \multirow[t]{2}{*}{ Sales \& Clerical } & 0.072 & 0.071 & 0.075 \\
\hline & $(1.80)^{*}$ & $(1.78)^{*}$ & $(1.82)^{*}$ \\
\hline \multirow[t]{2}{*}{ Blue Collar Jobs } & -0.023 & -0.025 & -0.024 \\
\hline & $(0.33)$ & $(0.37)$ & $(0.34)$ \\
\hline \multirow[t]{2}{*}{ Occupation Unspecified } & -0.065 & -0.064 & -0.067 \\
\hline & $(0.97)$ & $(0.96)$ & $(0.97)$ \\
\hline \multirow[t]{2}{*}{ South } & -0.115 & -0.126 & -0.132 \\
\hline & $(2.42)^{* *}$ & $(2.50)^{* *}$ & $(2.47)^{* *}$ \\
\hline \multirow[t]{2}{*}{ Metro } & -0.020 & -0.012 & -0.013 \\
\hline & $(0.29)$ & $(0.17)$ & $(0.18)$ \\
\hline \multirow[t]{2}{*}{ Foreign Born } & -0.032 & -0.024 & -0.023 \\
\hline & $(0.63)$ & $(0.48)$ & $(0.45)$ \\
\hline \multirow[t]{2}{*}{ Interview Time Trend } & -0.0005 & -0.0005 & -0.0006 \\
\hline & $(0.19)$ & $(0.18)$ & $(0.22)$ \\
\hline \multirow[t]{2}{*}{ Concentration Ratio } & & -0.001 & -0.001 \\
\hline & & $(0.98)$ & $(0.96)$ \\
\hline \multirow[t]{2}{*}{ Constant } & 1.674 & 1.689 & \\
\hline & $(5.27)^{* * *}$ & $(5.39)^{* * *}$ & \\
\hline Observations & 1278 & 1278 & 1278 \\
\hline R-squared & 0.06 & 0.06 & 0.05 \\
\hline
\end{tabular}

Notes:

(1) The dependent variable equals unity if the respondent reported his earnings, otherwise it is zero.

(2) Robust t statistics in parentheses.

(2) * significant at $10 \%$; ** significant at $5 \%$; *** significant at $1 \%$.

(3) All the regressions are weighed using respondent weights.

Source: National Jewish Population Survey 2000/01 
Table 2. The Determinants of Earnings among Adult Male Respondents, NJPS 2000/01, (OLS)

\begin{tabular}{|c|c|c|c|c|c|c|}
\hline & $\begin{array}{c}(1) \\
\text { Nativity } \\
\text { Status } \\
\end{array}$ & $\begin{array}{c}(2) \\
\text { Country of } \\
\text { Birth } \\
\end{array}$ & $\begin{array}{c}\text { (3) } \\
\text { Country of } \\
\text { Birth } \\
\end{array}$ & $\begin{array}{c}(4) \\
\text { Denomination } \\
\text { Raised } \\
\end{array}$ & $\begin{array}{c}(5) \\
\text { Current } \\
\text { Denomination }\end{array}$ & $\begin{array}{c}(6) \\
\text { Current } \\
\text { Denomination }\end{array}$ \\
\hline Schooling (Years) & $\begin{array}{l}0.110 \\
(8.62)^{* * *}\end{array}$ & $\begin{array}{l}0.113 \\
(8.87)^{* * *}\end{array}$ & $\begin{array}{l}0.113 \\
(8.85)^{* * *}\end{array}$ & $\begin{array}{l}0.108 \\
(8.00)^{* * *}\end{array}$ & $\begin{array}{l}0.111 \\
(8.26)^{* * *}\end{array}$ & $\begin{array}{l}0.109 \\
(8.02)^{* * *}\end{array}$ \\
\hline Experience (Years) & $\begin{array}{l}0.022 \\
(1.52)\end{array}$ & $\begin{array}{l}0.022 \\
(1.53)\end{array}$ & $\begin{array}{l}0.022 \\
(1.53)\end{array}$ & $\begin{array}{l}0.024 \\
(1.63)\end{array}$ & $\begin{array}{l}0.021 \\
(1.41)\end{array}$ & $\begin{array}{l}0.021 \\
(1.41)\end{array}$ \\
\hline Experience Squared & $\begin{array}{l}-0.00050 \\
(-1.65)^{*}\end{array}$ & $\begin{array}{l}-0.00051 \\
(-1.66)^{*}\end{array}$ & $\begin{array}{l}-0.00051 \\
(-1.66)^{*}\end{array}$ & $\begin{array}{l}-0.00055 \\
(-1.73)^{*}\end{array}$ & $\begin{array}{l}-0.00044 \\
(-1.40)\end{array}$ & $\begin{array}{l}-0.00043 \\
(-1.36)\end{array}$ \\
\hline Widowed/ Divorced/ Separated & $\begin{array}{l}-0.062 \\
(-0.66)\end{array}$ & $\begin{array}{l}-0.054 \\
(-0.60)\end{array}$ & $\begin{array}{l}-0.054 \\
(-0.60)\end{array}$ & $\begin{array}{l}-0.039 \\
(-0.41)\end{array}$ & $\begin{array}{l}-0.060 \\
(-0.63)\end{array}$ & $\begin{array}{l}-0.055 \\
(-0.57)\end{array}$ \\
\hline Never Married & $\begin{array}{l}-0.273 \\
(-3.41)^{* * *}\end{array}$ & $\begin{array}{l}-0.281 \\
(-3.45)^{* * *}\end{array}$ & $\begin{array}{l}-0.281 \\
(-3.45)^{* * *}\end{array}$ & $\begin{array}{l}-0.267 \\
(-3.27)^{* * *}\end{array}$ & $\begin{array}{l}-0.271 \\
(-3.36)^{* * *}\end{array}$ & $\begin{array}{l}-0.267 \\
(-3.27)^{* * *}\end{array}$ \\
\hline Foreign Born & $\begin{array}{l}-0.228 \\
(-1.52)\end{array}$ & & & & & \\
\hline Year Since Migration & $\begin{array}{l}0.010 \\
(1.76)^{*}\end{array}$ & $\begin{array}{l}0.004 \\
(0.49)\end{array}$ & $\begin{array}{l}0.003 \\
(0.46)\end{array}$ & & & \\
\hline South & $\begin{array}{l}0.017 \\
(0.19)\end{array}$ & $\begin{array}{l}0.024 \\
(0.29)\end{array}$ & $\begin{array}{l}0.024 \\
(0.29)\end{array}$ & $\begin{array}{l}0.032 \\
(0.39)\end{array}$ & $\begin{array}{l}0.006 \\
(0.07)\end{array}$ & $\begin{array}{l}0.005 \\
(0.07)\end{array}$ \\
\hline Metropolitan Area & $\begin{array}{l}-0.102 \\
(-0.73)\end{array}$ & $\begin{array}{l}-0.104 \\
(-0.74)\end{array}$ & $\begin{array}{l}-0.104 \\
(-0.74)\end{array}$ & $\begin{array}{l}-0.122 \\
(-0.85)\end{array}$ & $\begin{array}{l}-0.086 \\
(-0.61)\end{array}$ & $\begin{array}{l}-0.095 \\
(-0.67)\end{array}$ \\
\hline Developed Countries & & $\begin{array}{l}0.106 \\
(0.34)\end{array}$ & $\begin{array}{l}0.108 \\
(0.34)\end{array}$ & & & \\
\hline Former Soviet Union (FSU) & & $\begin{array}{l}-0.365 \\
(-2.59)^{* * *}\end{array}$ & $\begin{array}{l}-0.377 \\
(-1.67)^{*}\end{array}$ & & & \\
\hline Israel & & $\begin{array}{l}0.180 \\
(0.49)\end{array}$ & $\begin{array}{l}0.182 \\
(0.49)\end{array}$ & & & \\
\hline Less Developed Countries & & $\begin{array}{l}-0.033 \\
(-0.16)\end{array}$ & $\begin{array}{l}-0.031 \\
(-0.15)\end{array}$ & & & \\
\hline Country Missing & & $\begin{array}{l}-0.583 \\
(-1.43)\end{array}$ & $\begin{array}{l}-0.581 \\
(-1.42)\end{array}$ & & & \\
\hline Year Since Migration*FSU & & & $\begin{array}{l}0.001 \\
(0.07)\end{array}$ & & & \\
\hline Orthodox & & & & $\begin{array}{l}-0.099 \\
(-0.82)\end{array}$ & $\begin{array}{l}-0.280 \\
(-1.99)^{* *}\end{array}$ & $\begin{array}{l}-0.290 \\
(-2.08)^{* *}\end{array}$ \\
\hline Reform & & & & $\begin{array}{l}-0.127 \\
(-1.49)\end{array}$ & $\begin{array}{l}-0.100 \\
(-0.97)\end{array}$ & $\begin{array}{l}-0.114 \\
-(1.13)\end{array}$ \\
\hline Just Jewish & & & & $\begin{array}{l}-0.152 \\
(-1.72)^{*}\end{array}$ & $\begin{array}{l}-0.078 \\
(-0.81)\end{array}$ & $\begin{array}{l}-0.103 \\
(-1.07)\end{array}$ \\
\hline Secular & & & & $\begin{array}{l}-0.401 \\
(-2.50)^{* *}\end{array}$ & $\begin{array}{l}-0.292 \\
(-2.27)^{* *}\end{array}$ & $\begin{array}{l}-0.321 \\
(-2.50)^{* *}\end{array}$ \\
\hline Non Jews & & & & $\begin{array}{l}-0.367 \\
(-2.49)^{* *}\end{array}$ & $\begin{array}{l}-0.389 \\
(-1.49)\end{array}$ & $\begin{array}{l}-0.424 \\
(-1.62)\end{array}$ \\
\hline Denomination Missing & & & & $\begin{array}{l}-0.130 \\
(-1.36)\end{array}$ & $\begin{array}{l}-0.006 \\
(-0.05)\end{array}$ & $\begin{array}{l}-0.028 \\
(-0.26)\end{array}$ \\
\hline
\end{tabular}


Convert

$-0.306$

\begin{tabular}{|c|c|c|c|c|c|c|}
\hline & & & & & & $(-1.37)$ \\
\hline Constant & $\begin{array}{l}9.322 \\
(30.59) * * *\end{array}$ & $\begin{array}{l}9.280 \\
(30.38)^{* * *}\end{array}$ & $\begin{array}{l}9.279 \\
(30.33)^{* * *}\end{array}$ & $\begin{array}{l}9.451 \\
(29.80)^{* * *}\end{array}$ & $\begin{array}{l}9.360 \\
(29.65)^{* * *}\end{array}$ & $\begin{array}{l}9.420 \\
(29.40)^{* * *}\end{array}$ \\
\hline Observations & 835 & 835 & 835 & 837 & 837 & 837 \\
\hline R-squared & 0.16 & 0.17 & 0.17 & 0.17 & 0.17 & 0.18 \\
\hline
\end{tabular}

Notes:

(1) The dependent variable is the natural logarithm of annual earnings for males age 25 to 64 who worked full-time or parttime with earnings.

(2) Robust t statistics in parentheses.

(3) * significant at $10 \%$; ** significant at $5 \%$; *** significant at $1 \%$.

(4) All the regressions are weighed using respondent weights.

Source: National Jewish Population Survey 2000/01 
Table 3. The Determinants of Earnings among Adult Male Respondents, NJPS 2000/01, (Heckman Selection Model)

\begin{tabular}{|c|c|c|c|c|c|c|}
\hline & $\begin{array}{c}(1) \\
\text { Nativity } \\
\text { Status }\end{array}$ & $\begin{array}{c}\text { (2) } \\
\text { Country of } \\
\text { Birth }\end{array}$ & $\begin{array}{c}\text { (3) } \\
\text { Country of } \\
\text { Birth } \\
\end{array}$ & $\begin{array}{c}(4) \\
\text { Denomination } \\
\text { Raised } \\
\end{array}$ & $\begin{array}{c}(5) \\
\text { Current } \\
\text { Denomination }\end{array}$ & $\begin{array}{c}(6) \\
\text { Current } \\
\text { Denomination } \\
\end{array}$ \\
\hline Schooling (Years) & $\begin{array}{l}0.098 \\
(6.86)^{* * *}\end{array}$ & $\begin{array}{l}0.100 \\
(7.08)^{* * *}\end{array}$ & $\begin{array}{l}0.100 \\
(7.08)^{* * *}\end{array}$ & $\begin{array}{l}0.095 \\
(6.46)^{* * *}\end{array}$ & $\begin{array}{l}0.100 \\
(6.69)^{* * *}\end{array}$ & $\begin{array}{l}0.097 \\
(6.43)^{* * *}\end{array}$ \\
\hline Experience (Years) & $\begin{array}{l}0.003 \\
(0.21)\end{array}$ & $\begin{array}{l}0.004 \\
(0.23)\end{array}$ & $\begin{array}{l}0.004 \\
(0.23)\end{array}$ & $\begin{array}{l}0.005 \\
(0.31)\end{array}$ & $\begin{array}{l}0.001 \\
(0.06)\end{array}$ & $\begin{array}{l}0.001 \\
(0.03)\end{array}$ \\
\hline Experience Squared & $\begin{array}{l}-0.00023 \\
(-0.71)\end{array}$ & $\begin{array}{l}-0.00023 \\
(-0.71)\end{array}$ & $\begin{array}{l}-0.00023 \\
(-0.71)\end{array}$ & $\begin{array}{l}-0.00026 \\
(-0.79)\end{array}$ & $\begin{array}{l}-0.00014 \\
(-0.43)\end{array}$ & $\begin{array}{l}-0.00012 \\
(-0.37)\end{array}$ \\
\hline Widowed/ Divorced/ Separated & $\begin{array}{l}0.031 \\
(0.30)\end{array}$ & $\begin{array}{l}0.036 \\
(0.36)\end{array}$ & $\begin{array}{l}0.036 \\
(0.37)\end{array}$ & $\begin{array}{l}0.049 \\
(0.46)\end{array}$ & $\begin{array}{l}0.028 \\
(0.27)\end{array}$ & $\begin{array}{l}0.036 \\
(0.35)\end{array}$ \\
\hline Never Married & $\begin{array}{l}-0.223 \\
(-2.55)^{* *}\end{array}$ & $\begin{array}{l}-0.232 \\
(-2.65)^{* * *}\end{array}$ & $\begin{array}{l}-0.232 \\
(-2.64)^{* * *}\end{array}$ & $\begin{array}{l}-0.216 \\
(-2.45)^{* *}\end{array}$ & $\begin{array}{l}-0.225 \\
(-2.61)^{* * *}\end{array}$ & $\begin{array}{l}-0.218 \\
(-2.48)^{* *}\end{array}$ \\
\hline Foreign Born & $\begin{array}{l}-0.259 \\
(-1.80)^{*}\end{array}$ & & & & & \\
\hline Year Since Migration & $\begin{array}{l}0.009 \\
(1.70)^{*}\end{array}$ & $\begin{array}{l}0.003 \\
(0.49)\end{array}$ & $\begin{array}{l}0.003 \\
(0.39)\end{array}$ & & & \\
\hline South & $\begin{array}{l}-0.093 \\
(-0.97)\end{array}$ & $\begin{array}{l}-0.084 \\
(-0.89)\end{array}$ & $\begin{array}{l}-0.085 \\
(-0.90)\end{array}$ & $\begin{array}{l}-0.078 \\
(-0.83)\end{array}$ & $\begin{array}{l}-0.108 \\
(-1.14)\end{array}$ & $\begin{array}{l}-0.111 \\
(-1.17)\end{array}$ \\
\hline Metropolitan Area & $\begin{array}{l}-0.103 \\
(-0.66)\end{array}$ & $\begin{array}{l}-0.106 \\
(-0.68)\end{array}$ & $\begin{array}{l}-0.106 \\
(-0.68)\end{array}$ & $\begin{array}{l}-0.131 \\
(-0.82)\end{array}$ & $\begin{array}{l}-0.087 \\
(-0.56)\end{array}$ & $\begin{array}{l}-0.096 \\
(-0.61)\end{array}$ \\
\hline Developed Countries & & $\begin{array}{l}0.033 \\
(0.12)\end{array}$ & $\begin{array}{l}0.048 \\
(0.17)\end{array}$ & & & \\
\hline Former Soviet Union (FSU) & & $\begin{array}{l}-0.393 \\
(-2.69)^{* * *}\end{array}$ & $\begin{array}{l}-0.491 \\
(-2.08)^{* *}\end{array}$ & & & \\
\hline Israel & & $\begin{array}{l}0.046 \\
(0.13)\end{array}$ & $\begin{array}{l}0.057 \\
(0.16)\end{array}$ & & & \\
\hline Less Developed Countries & & $\begin{array}{l}-0.034 \\
(-0.19)\end{array}$ & $\begin{array}{l}-0.024 \\
(-0.13)\end{array}$ & & & \\
\hline Country Missing & & $\begin{array}{l}-0.581 \\
(-1.48)\end{array}$ & $\begin{array}{l}-0.570 \\
(-1.45)\end{array}$ & & & \\
\hline Year Since Migration*FSU & & & $\begin{array}{l}0.009 \\
(0.60)\end{array}$ & & & \\
\hline Orthodox & & & & $\begin{array}{l}-0.138 \\
(-1.19)\end{array}$ & $\begin{array}{l}-0.276 \\
(-2.06)^{* *}\end{array}$ & $\begin{array}{l}-0.288 \\
(-2.18)^{* *}\end{array}$ \\
\hline Reform & & & & $\begin{array}{l}-0.120 \\
(1.51)\end{array}$ & $\begin{array}{l}-0.073 \\
(0.71)\end{array}$ & $\begin{array}{l}-0.088 \\
(0.88)\end{array}$ \\
\hline Just Jewish & & & & $\begin{array}{l}-0.122 \\
(-1.46)\end{array}$ & $\begin{array}{l}-0.021 \\
(-0.22)\end{array}$ & $\begin{array}{l}-0.047 \\
(-0.51)\end{array}$ \\
\hline Secular & & & & $\begin{array}{l}-0.369 \\
(-2.22)^{* *}\end{array}$ & $\begin{array}{l}-0.253 \\
(-1.79)^{*}\end{array}$ & $\begin{array}{l}-0.286 \\
(-2.03)^{* *}\end{array}$ \\
\hline Non Jews & & & & $\begin{array}{l}-0.334 \\
(-2.47)^{* *}\end{array}$ & $\begin{array}{l}-0.379 \\
(-1.39)\end{array}$ & $\begin{array}{l}-0.420 \\
(-1.53)\end{array}$ \\
\hline Denomination Missing & & & & $\begin{array}{l}-0.138 \\
(-1.51)\end{array}$ & $\begin{array}{l}0.044 \\
(0.41)\end{array}$ & $\begin{array}{l}0.021 \\
(0.20)\end{array}$ \\
\hline
\end{tabular}


Convert

$-0.363$

$(-1.36)$

\begin{tabular}{lllllll} 
Constant & 9.426 & 9.390 & 9.387 & 9.571 & 9.418 & 9.484 \\
& $(28.15)^{* * *}$ & $(28.10)^{* * *}$ & $(28.08)^{* * *}$ & $(27.74)^{* * *}$ & $(27.67)^{* * *}$ & $(27.50)^{* * *}$ \\
\hline Rho & $0.756^{* * *}$ & $0.754^{* * *}$ & $0.755^{* * *}$ & $0.762^{* * *}$ & $0.766^{* * *}$ & $0.782^{* * *}$ \\
Sigma & $0.861^{* * *}$ & $0.855^{* * *}$ & $0.855^{* * *}$ & $0.860^{* * *}$ & $0.859^{* * *}$ & $0.864^{* * *}$ \\
Lambda & $0.651^{* * *}$ & $0.644^{* * *}$ & $0.646^{* * *}$ & $0.655^{* * *}$ & $0.658^{* * *}$ & $0.676^{* * *}$ \\
& $(8.03)$ & $(7.82)$ & $(7.82)$ & $(8.08)$ & $(8.29)$ & $(8.99)$ \\
\hline Observations & 835 & 835 & 835 & 837 & 837 & 837 \\
\hline
\end{tabular}

Notes:

(1) The dependent variable is the natural logarithm of annual earnings for males age 25 to 64 who worked full-time or part-time with earnings.

(2) Robust t statistics in parentheses.

(3) * significant at $10 \%$; ** significant at 5\%; *** significant at $1 \%$.

(4) All the regressions are weighed using respondent weights.

Source: National Jewish Population Survey 2000/01 
Table 4. The Determinants of Earnings among Adult Male Respondents, NJPS 2000/01, (OLS)

\begin{tabular}{|c|c|c|c|c|c|c|}
\hline & $\begin{array}{c}(1) \\
\text { Nativity } \\
\text { Status } \\
\end{array}$ & $\begin{array}{c}\text { (2) } \\
\text { Country of } \\
\text { Birth } \\
\end{array}$ & $\begin{array}{c}\text { (3) } \\
\text { Country of } \\
\text { Birth } \\
\end{array}$ & $\begin{array}{c}(4) \\
\text { Denomination } \\
\text { Raised }\end{array}$ & $\begin{array}{c}(5) \\
\text { Current } \\
\text { Denomination }\end{array}$ & $\begin{array}{c}(6) \\
\text { Current } \\
\text { Denomination }\end{array}$ \\
\hline Schooling (Years) & $\begin{array}{l}0.112 \\
(8.41)^{* * *}\end{array}$ & $\begin{array}{l}0.116 \\
(8.75) * * *\end{array}$ & $\begin{array}{l}0.116 \\
(8.73)^{* * *}\end{array}$ & $\begin{array}{l}0.116 \\
(8.32)^{* * * *}\end{array}$ & $\begin{array}{l}0.109 \\
(7.73)^{* * *}\end{array}$ & $\begin{array}{l}0.109 \\
(7.73)^{* * *}\end{array}$ \\
\hline Jewish Ed: Day School (8-12) & $\begin{array}{l}0.035 \\
(0.22)\end{array}$ & $\begin{array}{l}0.028 \\
(0.19)\end{array}$ & $\begin{array}{l}0.028 \\
(0.19)\end{array}$ & $\begin{array}{l}0.103 \\
(0.70)\end{array}$ & $\begin{array}{l}0.295 \\
(2.22)^{* *}\end{array}$ & $\begin{array}{l}0.294 \\
(2.21)^{* *}\end{array}$ \\
\hline Jewish Ed: Other (8-12) & $\begin{array}{l}0.012 \\
(0.16)\end{array}$ & $\begin{array}{l}-0.010 \\
(0.14)\end{array}$ & $\begin{array}{l}-0.011 \\
(0.14)\end{array}$ & $\begin{array}{l}0.022 \\
(0.27)\end{array}$ & $\begin{array}{l}0.032 \\
(0.42)\end{array}$ & $\begin{array}{l}0.032 \\
(0.42)\end{array}$ \\
\hline Experience (Years) & $\begin{array}{l}0.025 \\
(1.64)\end{array}$ & $\begin{array}{l}0.025 \\
(1.65)^{*}\end{array}$ & $\begin{array}{l}0.025 \\
(1.65)\end{array}$ & $\begin{array}{l}0.026 \\
(1.73)^{*}\end{array}$ & $\begin{array}{l}0.025 \\
(1.67)^{*}\end{array}$ & $\begin{array}{l}0.025 \\
(1.66)^{*}\end{array}$ \\
\hline Experience Squared & $\begin{array}{l}-0.001 \\
(1.69)^{*}\end{array}$ & $\begin{array}{l}-0.001 \\
(1.68)^{*}\end{array}$ & $\begin{array}{l}-0.001 \\
(1.67)^{*}\end{array}$ & $\begin{array}{l}-0.001 \\
(1.68)^{*}\end{array}$ & $\begin{array}{l}-0.000 \\
(1.52)\end{array}$ & $\begin{array}{l}-0.000 \\
(1.52)\end{array}$ \\
\hline Widowed/ Divorced/ Separated & $\begin{array}{l}-0.055 \\
(0.57)\end{array}$ & $\begin{array}{l}-0.046 \\
(0.50)\end{array}$ & $\begin{array}{l}-0.046 \\
(0.50)\end{array}$ & $\begin{array}{l}-0.031 \\
(0.32)\end{array}$ & $\begin{array}{l}-0.050 \\
(0.51)\end{array}$ & $\begin{array}{l}-0.050 \\
(0.50)\end{array}$ \\
\hline Never Married & $\begin{array}{l}-0.217 \\
(2.63)^{* * *}\end{array}$ & $\begin{array}{l}-0.223 \\
(2.70)^{* * *}\end{array}$ & $\begin{array}{l}-0.223 \\
(2.69)^{* * *}\end{array}$ & $\begin{array}{l}-0.212 \\
(2.61)^{* * *}\end{array}$ & $\begin{array}{l}-0.182 \\
(2.26)^{* *}\end{array}$ & $\begin{array}{l}-0.182 \\
(2.25)^{* *}\end{array}$ \\
\hline Foreign Born & $\begin{array}{l}-0.200 \\
(1.16)\end{array}$ & & & & & \\
\hline Year Since Migration & $\begin{array}{l}0.008 \\
(1.30)\end{array}$ & $\begin{array}{l}-0.001 \\
(0.08)\end{array}$ & $\begin{array}{l}-0.001 \\
(0.12)\end{array}$ & & & \\
\hline South & $\begin{array}{l}0.015 \\
(0.17)\end{array}$ & $\begin{array}{l}0.024 \\
(0.28)\end{array}$ & $\begin{array}{l}0.023 \\
(0.28)\end{array}$ & $\begin{array}{l}0.033 \\
(0.40)\end{array}$ & $\begin{array}{l}-0.011 \\
(0.12)\end{array}$ & $\begin{array}{l}-0.011 \\
(0.12)\end{array}$ \\
\hline Metropolitan Area & $\begin{array}{l}-0.107 \\
(0.70)\end{array}$ & $\begin{array}{l}-0.111 \\
(0.72)\end{array}$ & $\begin{array}{l}-0.111 \\
(0.72)\end{array}$ & $\begin{array}{l}-0.096 \\
(0.63)\end{array}$ & $\begin{array}{l}-0.080 \\
(0.53)\end{array}$ & $\begin{array}{l}-0.080 \\
(0.52)\end{array}$ \\
\hline Developed Countries & & $\begin{array}{l}0.194 \\
(0.57)\end{array}$ & $\begin{array}{l}0.206 \\
(0.58)\end{array}$ & & & \\
\hline Former Soviet Union (FSU) & & $\begin{array}{l}-0.340 \\
(2.25)^{* *}\end{array}$ & $\begin{array}{l}-0.400 \\
(1.77)^{*}\end{array}$ & & & \\
\hline Israel & & $\begin{array}{l}0.251 \\
(0.66)\end{array}$ & $\begin{array}{l}0.260 \\
(0.67)\end{array}$ & & & \\
\hline Less Developed Countries & & $\begin{array}{l}0.181 \\
(0.64)\end{array}$ & $\begin{array}{l}0.192 \\
(0.64)\end{array}$ & & & \\
\hline Country Missing & & $\begin{array}{l}-0.522 \\
(1.28)\end{array}$ & $\begin{array}{l}-0.513 \\
(1.24)\end{array}$ & & & \\
\hline Year Since Migration*FSU & & & $\begin{array}{l}0.006 \\
(0.35)\end{array}$ & & & \\
\hline Orthodox & & & & $\begin{array}{l}-0.130 \\
(1.10)\end{array}$ & $\begin{array}{l}-0.477 \\
(3.86)^{* * *}\end{array}$ & $\begin{array}{l}-0.477 \\
(3.86)^{* * *}\end{array}$ \\
\hline Reform & & & & $\begin{array}{l}-0.117 \\
(1.34)\end{array}$ & $\begin{array}{l}-0.104 \\
(1.14)\end{array}$ & $\begin{array}{l}-0.105 \\
(1.12)\end{array}$ \\
\hline Just Jewish & & & & $\begin{array}{l}-0.139 \\
(1.51)\end{array}$ & $\begin{array}{l}-0.129 \\
(1.44)\end{array}$ & $\begin{array}{l}-0.129 \\
(1.42)\end{array}$ \\
\hline Secular & & & & $\begin{array}{l}-0.382 \\
(2.41)^{* *}\end{array}$ & $\begin{array}{l}-0.419 \\
(3.43)^{* * *}\end{array}$ & $\begin{array}{l}-0.419 \\
(3.38)^{* * *}\end{array}$ \\
\hline
\end{tabular}


Non Jews

$\begin{array}{lll}-0.333 & -0.440 & -0.441\end{array}$

Denomination Missing

$(2.21)^{* *}$

(1.37)

(1.37)

$0.002-0.000$

$-0.000$

(0.02)

(0.00)

$(0.00)$

Convert

$-0.005$

$(0.02)$

\begin{tabular}{lllllll} 
Constant & 9.270 & 9.220 & 9.218 & 9.231 & 9.343 & 9.343 \\
& $(29.52)^{* * *}$ & $(29.32)^{* * *}$ & $(29.28)^{* * *}$ & $(28.91)^{* * *}$ & $\begin{array}{l}(28.29)^{* * *} \\
(28.09)^{* * *}\end{array}$ \\
\hline Observations & 794 & 794 & 794 & 796 & 796 & 796 \\
R-squared & 0.16 & 0.18 & 0.18 & 0.17 & 0.19 & 0.19 \\
\hline
\end{tabular}

Notes:

(1) The dependent variable is the natural logarithm of annual earnings for males age 25 to 64 who worked full-time or part-time with earnings.

(2) Robust t statistics in parentheses.

(3) * significant at $10 \%$; ** significant at $5 \%$; *** significant at $1 \%$.

(4) All the regressions are weighed using respondent weights.

Source: National Jewish Population Survey 2000/01 
Appendix A. Explanation of Variables

\begin{tabular}{|c|c|c|c|}
\hline Category & Variables & Explanations & Source from NJPS 2000/01 \\
\hline \multirow[t]{3}{*}{$\begin{array}{l}\text { Dependent } \\
\text { Variables }\end{array}$} & Earnings & $\begin{array}{l}\text { Earnings data are constructed from a categorical } \\
\text { variable (Q299_A) using a mid point method. (If the } \\
\text { earnings are, for example, between } \$ 15000 \text { and } \\
\$ 19999 \text {, a value of } \$ 17500 \text { is assigned. The value for } \\
\text { the highest category is obtained by multiplying its } \\
\text { lower bound by } 1.5 \text { ) }\end{array}$ & Q299_A \\
\hline & Log Earnings & Natural logarithm of earnings & Q299_A \\
\hline & Answer & $\begin{array}{l}\text { A dichotomous variable with } 1 \text { indicating those who } \\
\text { answered the earnings question, } 0 \text { indicating those } \\
\text { who refused to answer. }\end{array}$ & Q299_A, Q286_A1 \\
\hline \multirow{13}{*}{$\begin{array}{l}\text { Demographic } \\
\text { Variables }\end{array}$} & Schooling (Years) & Years of Schooling & Q030_A1 \\
\hline & Age (Years) & Age & Q007AB_A \\
\hline & Experience (Years) & Experience $=$ Age - Schooling -5 & \\
\hline & Married & Currently married & Q066_A \\
\hline & Widowed/Divorced/Separated & Currently widowed, divorced or separated & Q066_A \\
\hline & Never Married & Never married & Q066_A \\
\hline & Marital Status Missing & Marital status missing & Q066_A \\
\hline & Widowed & Currently widowed & Q066_A \\
\hline & Divorced & Currently divorced & Q066_A \\
\hline & Separated & Currently separated & Q066_A \\
\hline & South & $\begin{array}{l}\text { A dichotomous variable with } 1 \text { indicating if the } \\
\text { respondent resides in one of the states in the South }\end{array}$ & ZIPCEN4 \\
\hline & Metropolitan & $\begin{array}{l}\text { A dichotomous variable with } 1 \text { indicating residing in } \\
\text { a metropolitan area }\end{array}$ & METSTAT \\
\hline & Concentration Ratio & $\begin{array}{l}\text { The percentage of respondents in a particular state } \\
\text { among all NJPS 2000/01 respondents }\end{array}$ & STATE \\
\hline \multirow[t]{2}{*}{$\begin{array}{l}\text { Foreign Born } \\
\text { Status }\end{array}$} & Foreign Born & $\begin{array}{l}\text { A dichotomous variable with } 1 \text { indicating those who } \\
\text { were not born in the US }\end{array}$ & Q052_A \\
\hline & Yeas Since Migration & $\begin{array}{l}\text { Year since migration }=2000.5-\text { Q055_A(year came } \\
\text { to the US) }\end{array}$ & Q055_A \\
\hline \multirow[t]{5}{*}{$\begin{array}{l}\text { Foreign } \\
\text { Country of } \\
\text { Birth }\end{array}$} & Former Soviet Union & $\begin{array}{l}\text { Countries that were part of the former Soviet Union, } \\
\text { includes for example Belarus, Georgia, Lithuania, } \\
\text { Russia, Ukraine etc. }\end{array}$ & Q054_A \\
\hline & Israel & Israel & Q054_A \\
\hline & Developed Countries & $\begin{array}{l}\text { European countries exclude those that were part of } \\
\text { the former Soviet Union countries, Canada, } \\
\text { Australia, New Zealand, Japan, and South Africa }\end{array}$ & Q054_A \\
\hline & Less Developed Countries & $\begin{array}{l}\text { Countries in Latin America, Middle East (excluding } \\
\text { Israel), Africa (excluding South Africa), and Asia } \\
\text { (excluding Japan). }\end{array}$ & Q054_A \\
\hline & Country Missing & Country of birth missing (foreign-born) & Q054_A \\
\hline $\begin{array}{l}\text { Conversion to } \\
\text { Judaism }\end{array}$ & Convert & $\begin{array}{l}\text { Those who are not born Jewish but converted to } \\
\text { Judaism }\end{array}$ & Q018_A \\
\hline \multirow{5}{*}{$\begin{array}{l}\text { Current Jewish } \\
\text { Denomination }\end{array}$} & Conservative & Conservative, Conservadox; Reconstructionist, & Q114_A1 -Q114_A7 \\
\hline & Orthodox & $\begin{array}{l}\text { Hasidic, Lubavitch, Satmar, Haredi; Orthodox, } \\
\text { Traditional (Jewish) }\end{array}$ & Q114_A1 - Q114_A7 \\
\hline & Reform & $\begin{array}{l}\text { Reform and Liberal (Jewish); Post-denominational, } \\
\text { Jewish Renewal }\end{array}$ & Q114_A1 - Q114_A7 \\
\hline & Just Jewish & $\begin{array}{l}\text { Just Jewish, Sephardic, Israelite/Hebrew, No Jewish } \\
\text { denomination, Other Jewish }\end{array}$ & Q114_A1 - Q114_A7 \\
\hline & Secular & $\begin{array}{l}\text { Secular, Ethnically/Nationality Jewish, Culturally } \\
\text { Jewish, Humanistic Jews, non-practicing Jews; } \\
\text { Jewish by background/birth/heritage, Agnostic, } \\
\text { Atheist, No religion/none/(nothing Jewish), Other }\end{array}$ & Q114_A1 - Q114_A7 \\
\hline
\end{tabular}




\begin{tabular}{|c|c|c|c|}
\hline & Non Jews & $\begin{array}{l}\text { Messianic (e.g., Jews for Jesus), Catholic, Protestant, } \\
\text { Mormon, and Other Christian religions }\end{array}$ & Q114_A1 - Q114_A7 \\
\hline & Denomination Missing & Current Jewish denomination missing & Q114_A1 - Q114_A7 \\
\hline \multirow{7}{*}{$\begin{array}{l}\text { Jewish } \\
\text { Denomination } \\
\text { Raised }\end{array}$} & Conservative & Conservative, Conservadox; Reconstructionist, & Q115_A1 - Q115_A5 \\
\hline & Orthodox & $\begin{array}{l}\text { Hasidic, Lubavitch, Satmar, Haredi; Orthodox, } \\
\text { Traditional (Jewish) }\end{array}$ & Q115_A1 -Q115_A5 \\
\hline & Reform & $\begin{array}{l}\text { Reform and Liberal (Jewish); Post-denominational, } \\
\text { Jewish Renewal }\end{array}$ & Q115_A1-Q115_A5 \\
\hline & Just Jewish & $\begin{array}{l}\text { Just Jewish, Sephardic, Israelite/Hebrew, No Jewish } \\
\text { denomination, Other Jewish }\end{array}$ & Q115_A1 - Q115_A5 \\
\hline & Secular & $\begin{array}{l}\text { Secular, Ethnically/Nationality Jewish, Culturally } \\
\text { Jewish, Humanistic Jews, non-practicing Jews; } \\
\text { Jewish by background/birth/heritage, Agnostic, } \\
\text { Atheist, No religion/none/(nothing Jewish), Other }\end{array}$ & Q115_A1 - Q115_A5 \\
\hline & Non Jews & $\begin{array}{l}\text { Messianic (e.g., Jews for Jesus), Catholic, Protestant, } \\
\text { Mormon, and Other Christian religions }\end{array}$ & Q115_A1-Q115_A5 \\
\hline & Denomination Missing & Jewish denomination raised missing & Q115_A1-Q115_A5 \\
\hline \multirow[t]{7}{*}{$\begin{array}{l}\text { Jewish } \\
\text { Education }\end{array}$} & Grade 1 - 7: Day School & $\begin{array}{l}\text { “A full-time Jewish day school or yeshiva” or } \\
\text { "Israeli Secular/Public School” }\end{array}$ & Q168_A, Q169_A1-Q169_A4 \\
\hline & $\begin{array}{l}\text { Grade } 1 \text { - 7: Other Jewish } \\
\text { Education }\end{array}$ & $\begin{array}{l}\text { "A one-day-a-week Jewish education } \\
\text { program/Sunday school” or “A part-time Jewish } \\
\text { school that met more than once a week” or "Private } \\
\text { tutoring” or "Yiddish school/Workman’s } \\
\text { Circle/Arbiter Ring” or “Other informal Jewish } \\
\text { education” or "Jewish studies in public/private } \\
\text { school” or "Jewish home schooling” or "Unspecified } \\
\text { Jewish/Hebrew studies" }\end{array}$ & Q168_A, Q169_A1-Q169_A4 \\
\hline & Grade $1-7$ : None & $\begin{array}{l}\text { Did not have Jewish education, or Jewish education } \\
\text { type is "Summer Camp” or "Jewish } \\
\text { nursery/kindergarten" }\end{array}$ & Q168_A, Q169_A1-Q169_A4 \\
\hline & Grade 8 - 12: Day School & $\begin{array}{l}\text { “A full-time Jewish day school or yeshiva” or } \\
\text { "Israeli Secular/Public School” }\end{array}$ & Q171_A, Q172_A1-Q172_A4 \\
\hline & $\begin{array}{l}\text { Grade } 8 \text { - 12: Other Jewish } \\
\text { Education }\end{array}$ & $\begin{array}{l}\text { "A one-day-a-week Jewish education } \\
\text { program/Sunday school” or “A part-time Jewish } \\
\text { school that met more than once a week” or "Private } \\
\text { tutoring” or "Yiddish school/Workman's } \\
\text { Circle/Arbiter Ring” or "Other informal Jewish } \\
\text { education” or "Jewish studies in public/private } \\
\text { school” or "Jewish home schooling” or "Unspecified } \\
\text { Jewish/Hebrew studies” }\end{array}$ & Q171_A, Q172_A1-Q172_A4 \\
\hline & Grade 8 - 12: None & $\begin{array}{l}\text { Did not have Jewish education, or Jewish education } \\
\text { type is "Summer Camp" }\end{array}$ & Q171_A, Q172_A1-Q172_A4 \\
\hline & $\begin{array}{l}\text { Years Day School } \\
\text { (Grades 8-12) }\end{array}$ & $\begin{array}{l}\text { Years of Day School } \\
\text { (Grades 8-12) }\end{array}$ & $\begin{array}{l}\text { Q173 C_A, } \\
\text { Q173 G-A }\end{array}$ \\
\hline \multirow{5}{*}{$\begin{array}{l}\text { Occupation } \\
\text { Categories }\end{array}$} & Professional \& Managerial & Professional and Managerial occupations & Q289_A \\
\hline & Sales \& Clerical & Sales, Offices, Services occupations & Q289_A \\
\hline & Blue Collar Jobs & $\begin{array}{l}\text { Farming, Construction, Transportation and } \\
\text { Production occupations }\end{array}$ & Q289_A \\
\hline & Occupation Unspecified & Occupation unspecified & Q289_A \\
\hline & Occupation Not Asked & Occupation not asked $^{*}$ & Q289_A \\
\hline $\begin{array}{l}\text { Self-employed } \\
\text { Status }\end{array}$ & Self-employed & Self-employed status & Q293_A \\
\hline $\begin{array}{l}\text { Interview Time } \\
\text { Trend }\end{array}$ & Interview Time Trend & Interview Time Trend & REPLIC \\
\hline
\end{tabular}

Source: National Jewish Population Survey 2000/01

\footnotetext{
* Occupation asked only for respondents who reported that they had worked either full-time or part-time.
} 
Appendix B. Summary Statistics of the Sample

\begin{tabular}{|c|c|c|c|c|c|c|}
\hline Category & Variable & $\mathrm{N}$ & Mean & Std Dev & Minimum & Maximum \\
\hline \multirow{3}{*}{$\begin{array}{l}\text { Dependent } \\
\text { Variables }\end{array}$} & Earnings & 844 & 93289.750 & 118231.670 & 7500 & 750000 \\
\hline & Log Earnings & 844 & 11.078 & 0.810 & 8.923 & 13.528 \\
\hline & Answer & 1292 & 0.654 & 0.476 & 0 & 1 \\
\hline \multirow{13}{*}{$\begin{array}{l}\text { Demographic } \\
\text { Variables }\end{array}$} & Schooling (Years) & 1518 & 15.731 & 2.432 & 6 & 20 \\
\hline & Age (Years) & 1534 & 43.704 & 10.727 & 25 & 64 \\
\hline & Experience (Years) & 1518 & 22.950 & 10.793 & 2 & 50 \\
\hline & Married & 1534 & 0.617 & 0.496 & 0 & 1 \\
\hline & Widowed/Divorced/Separated & 1534 & 0.139 & 0.368 & 0 & 1 \\
\hline & Never Married & 1534 & 0.242 & 0.446 & 0 & 1 \\
\hline & Marital Status Missing & 1534 & 0.003 & 0.057 & 0 & 1 \\
\hline & Widowed & 1534 & 0.020 & 0.134 & 0 & 1 \\
\hline & Divorced & 1534 & 0.111 & 0.334 & 0 & 1 \\
\hline & Separated & 1534 & 0.008 & 0.122 & 0 & 1 \\
\hline & South & 1531 & 0.227 & 0.388 & 0 & 1 \\
\hline & Metropolitan & 1534 & 0.899 & 0.225 & 0 & 1 \\
\hline & Concentration Ratio & 1534 & 11.411 & 12.483 & 0.058 & 32.110 \\
\hline \multirow{7}{*}{$\begin{array}{l}\text { Foreign Born } \\
\text { Status } \\
\text { Foreign } \\
\text { Country of } \\
\text { Birth }\end{array}$} & Foreign Born & 1533 & 0.148 & 0.345 & 0 & 1 \\
\hline & Yeas Since Migration & 1530 & 2.945 & 8.895 & 0 & 60.5 \\
\hline & Former Soviet Union & 1534 & 0.051 & 0.217 & 0 & 1 \\
\hline & Israel & 1534 & 0.015 & 0.134 & 0 & 1 \\
\hline & Developed Countries & 1534 & 0.041 & 0.186 & 0 & 1 \\
\hline & Less Developed Countries & 1534 & 0.034 & 0.167 & 0 & 1 \\
\hline & Country Missing & 1534 & 0.006 & 0.076 & 0 & 1 \\
\hline \multirow{8}{*}{$\begin{array}{l}\text { Conversion } \\
\text { Current } \\
\text { Jewish } \\
\text { Denomination }\end{array}$} & Conversion to Judaism & 1534 & 0.027 & 0.157 & 0 & 1 \\
\hline & Conservative & 1534 & 0.171 & 0.403 & 0 & 1 \\
\hline & Orthodox & 1534 & 0.082 & 0.287 & 0 & 1 \\
\hline & Reform & 1534 & 0.246 & 0.446 & 0 & 1 \\
\hline & Just Jewish & 1534 & 0.156 & 0.390 & 0 & 1 \\
\hline & Secular & 1534 & 0.052 & 0.263 & 0 & 1 \\
\hline & Non Jews & 1534 & 0.008 & 0.098 & 0 & 1 \\
\hline & Denomination Missing & 1534 & 0.286 & 0.368 & 0 & 1 \\
\hline \multirow{7}{*}{$\begin{array}{l}\text { Jewish } \\
\text { Denomination } \\
\text { Raised }\end{array}$} & Conservative & 1534 & 0.234 & 0.442 & 0 & 1 \\
\hline & Orthodox & 1534 & 0.105 & 0.332 & 0 & 1 \\
\hline & Reform & 1534 & 0.214 & 0.428 & 0 & 1 \\
\hline & Just Jewish & 1534 & 0.099 & 0.316 & 0 & 1 \\
\hline & Secular & 1534 & 0.030 & 0.151 & 0 & 1 \\
\hline & Non Jews & 1534 & 0.007 & 0.072 & 0 & 1 \\
\hline & Denomination Missing & 1534 & 0.311 & 0.418 & 0 & 1 \\
\hline \multirow{7}{*}{$\begin{array}{l}\text { Jewish } \\
\text { Education }\end{array}$} & Grade 1 - 7: Day School & 1451 & 0.084 & 0.307 & 0 & 1 \\
\hline & Grade 1 - 7: Other Jewish Education & 1451 & 0.535 & 0.490 & 0 & 1 \\
\hline & Grade $1-7:$ None & 1451 & 0.374 & 0.451 & 0 & 1 \\
\hline & Grade 8 - 12: Day School & 1453 & 0.078 & 0.286 & 0 & 1 \\
\hline & Grade 8 - 12: Other Jewish Education & 1453 & 0.244 & 0.444 & 0 & 1 \\
\hline & Grade 8 - 12: None & 1453 & 0.671 & 0.482 & 0 & 1 \\
\hline & Years of Day School (Grades 8-12) & 1453 & 0.293 & 1.122 & 0 & 1 \\
\hline \multirow{3}{*}{$\begin{array}{l}\text { Occupation } \\
\text { Categories }\end{array}$} & Professional \& Managerial & 1534 & 0.544 & 0.497 & 0 & 1 \\
\hline & Sales \& Clerical & 1534 & 0.208 & 0.412 & 0 & 1 \\
\hline & Blue Collar Jobs & 1534 & 0.100 & 0.258 & 0 & 1 \\
\hline
\end{tabular}




\begin{tabular}{llccccr} 
& Occupation Unspecified & 1534 & 0.060 & 0.250 & 0 & 1 \\
& Occupation Not Asked & 1534 & 0.088 & 0.282 & 0 & 1 \\
Self- & & & & & & 1 \\
employed & Self-employed Status & 1534 & 0.147 & 0.401 & 0 & 22 \\
Time Trend & Interview Time Trend & 1534 & 11.874 & 6.245 & 1 & 22 \\
\hline
\end{tabular}

Notes: weighed using respondent weight

Source: National Jewish Population Survey, 2000/01 


\section{Appendix C \\ Cross Tabulation between Current Jewish Denomination and Jewish Denomination Raised (Unweighted)}

(CURRENT JEWISH DENOMINATION) (JEWISH DENOMINATION RAISED)

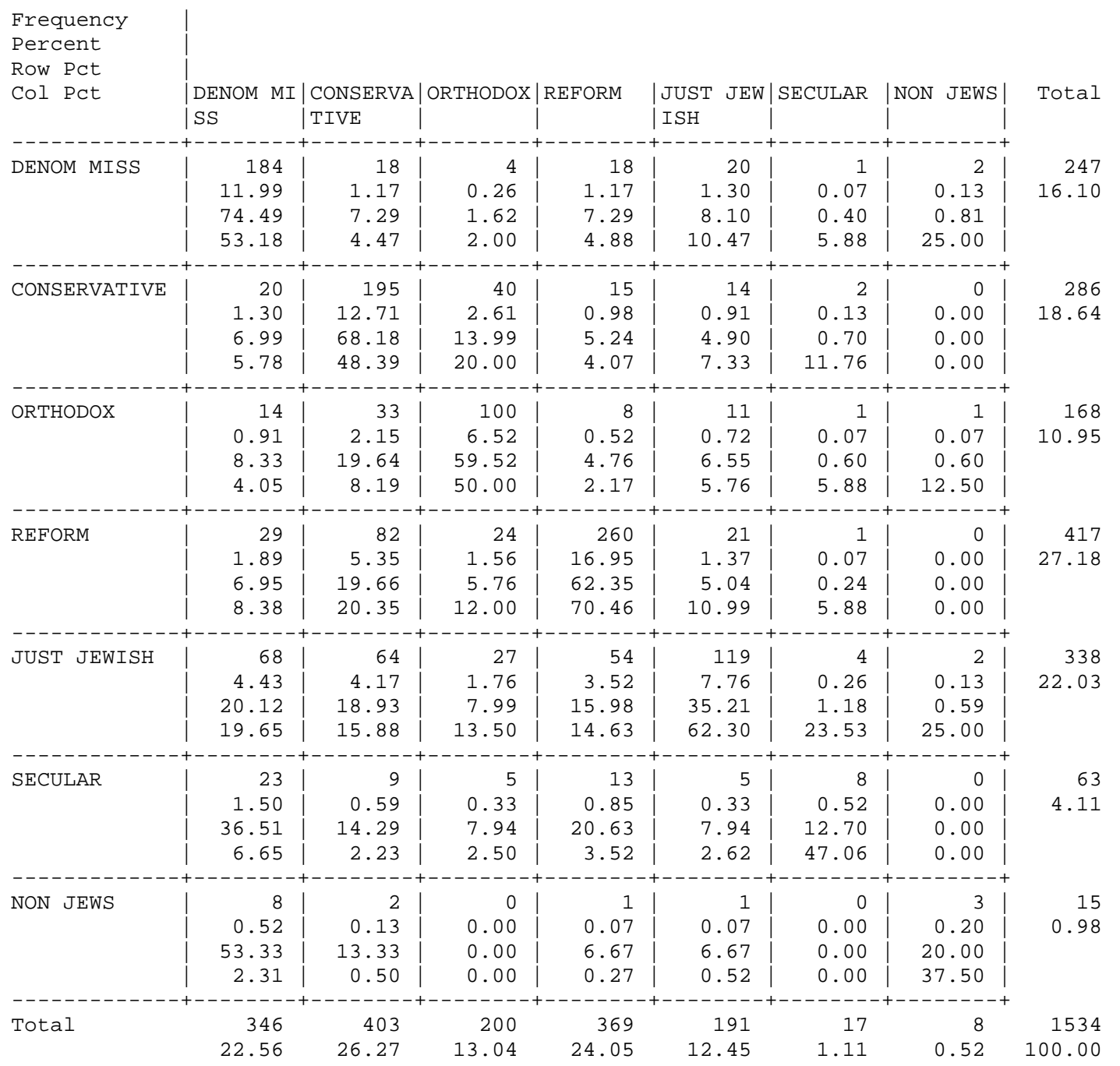

Source: National Jewish Population Survey, 2000/01 


\section{Appendix D \\ Cross Tabulation between Current Jewish Denomination and Jewish Denomination Raised (Weighted)}

(CURRENT JEWISH DENOMINATION) (JEWISH DENOMINATION RAISED)

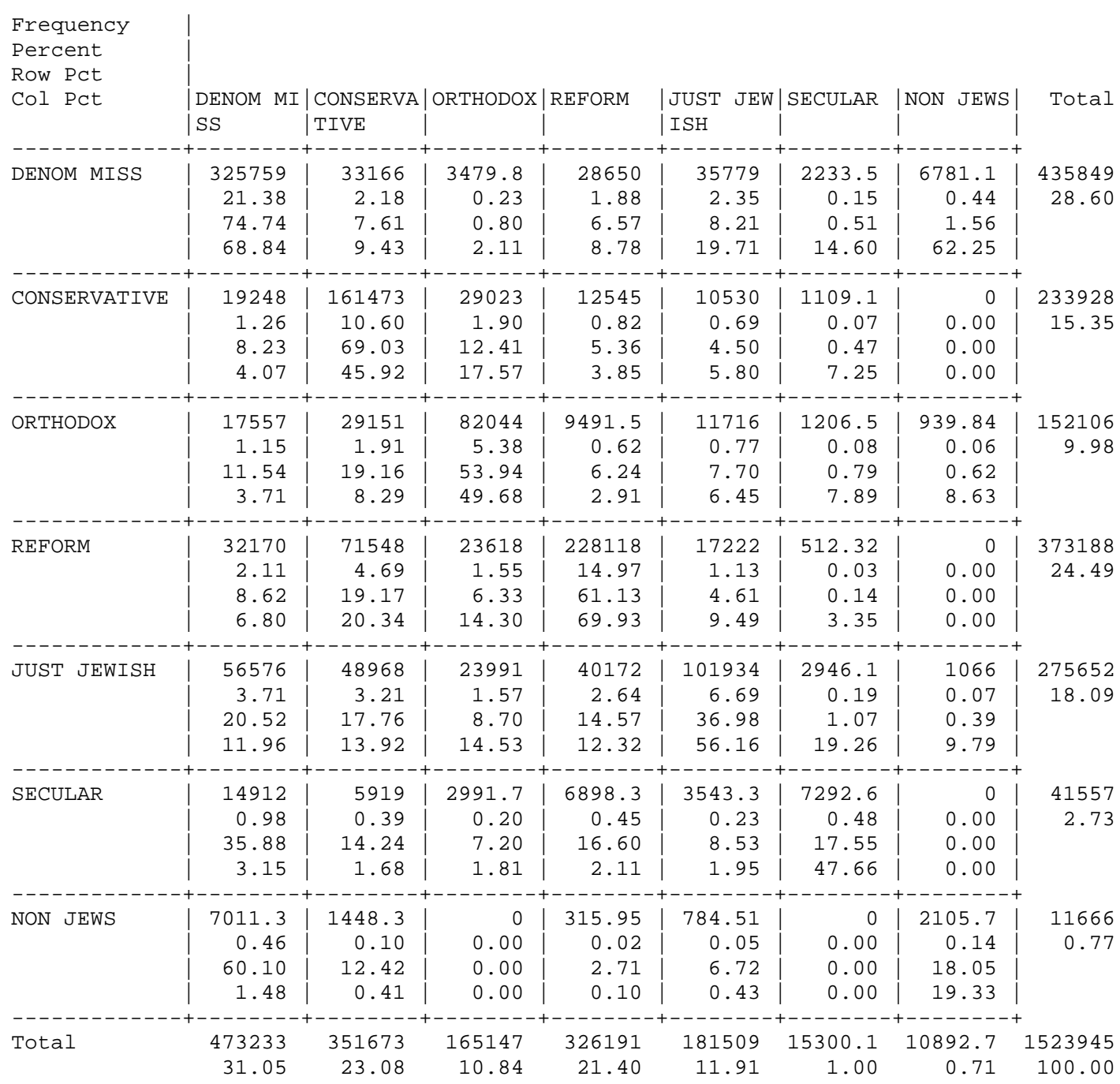

Source: National Jewish Population Survey, 2000/01 


\section{REFERENCES}

Billings, John S. (1890). Vital Statistics of the Jews in the United States, Census Bulletin No. 19, Census Office, Department of the Interior, Washington, D.C., December 30.

Burnstein, Paul (2005). "Jewish Educational and Economic Success in the United States: A Search for Explanations,” Department of Sociology, University of Washington, photocopy.

Chiswick, Barry R. (1988). "Differences in Education and Earnings Across Racial and Ethnic Groups: Tastes, Discrimination and Investments in Child Quality,” Quarterly Journal of Economics, August, pp. 571-597.

Chiswick, Barry R. (1993). "The Skills and the Economic Status of American Jewry: Trends Over the Last Half Century," Journal of Human Resources, 11(1), January, pp. 229-242.

Chiswick, Barry R. (1999). "The Occupational Attainment and Earnings of American Jewry, 1890-1990,” Contemporary Jewry, 20, pp. 68-98.

Chiswick, Barry R. (2001). "The Billings Report and the Occupational Attainment of American Jewry, 1890" Shofar: An Interdisciplinary Journal of Jewish Studies, 19(2), pp. 53-75.

Chiswick, Barry R. (2006). "The Occupational Attainment of American Jewry: 1990 to 2000” Department of Economics, University of Illinois at Chicago, photocopy.

Chiswick, Barry R. and Paul W. Miller (2005). "Do Enclaves Matter in Immigrant Adjustment?” City and Community, Vol. 4, No. 1, March, pp. 5-36.

Chiswick, Barry R. and Paul W. Miller (2006) "Why is the Payoff to Schooling Smaller for Immigrants?,” Department of Economics, University of Illinois at Chicago, photocopy.

Chiswick, Barry R. and Michael Wenz (2006). "The Linguistic and Economic Adjustment of Soviet Jewish Immigrants in the United States, 1980 to 2000" Research in Labor Economics, 24, pp. 179-216.

Chiswick, Carmel U. (2006). “An Economic Perspective on Religious Education: Complements and Substitutes in a Human Capital Portfolio,” Research in Labor Economics, 24, pp. 449-467.

Lehrer, Evelyn (2006a). "Religious Affiliation and Participation as Determinants of Women's Educational Attainment and Wages," in Robert Hummer and Christopher Ellison, eds., Religion, Family and Health in the United States. (forthcoming). 
Lehrer, Evelyn (2006b). "Young Women’s Religious Affiliation and Participation as Determinants of High School Graduation,” Department of Economics, University of Illinois at Chicago, February 15, Xerox.

Lieberson, Stanley and Mary C. Waters (1988) From Many Strands: Ethnic and Racial Groups in Contemporary America New York: Russell Sage Foundation

Smith, Tom W. (2005) Jewish Distinctiveness in America: A Statistical Portrait New York:American Jewish Committee

U.S. Bureau of the Census (1958). "Religion Reported by the Civilian Population of the United States: March 1957," Current Population Reports, Population Characteristics, Series p. 20, No. 72, February 2, 1958, Washington, D.C..

U.S. Bureau of the Census (no date) "Tabulations of Data on the Social and Economic Characteristics of Major Religious Groups, 1957,” Washington, D.C., mimeo. 